\title{
Rothia Dentocariosa'nın Etken Olduğu Parafarengeal Apse
}

\section{Parapharyngeal Abscess Caused by Rothia Dentocariosa}

Nurdoğan Ata ${ }^{1}$,

Selçuk Kılıç²,

Enver Ferruh İnan ${ }^{3}$

${ }^{1}$ Gaziantep 25 Aralık Devlet Hastanesi KBB Kliniği

${ }^{2}$ Ankara Refik Saydam Hifzıssıhha Merkezi Mikrobiyoloji Referans Laboratuvarı

${ }^{3}$ Konya Eğitim ve Araştırma Hastanesi KBB Kliniği

Gelis Tarihi/Received: 03 Ocak 2017

Kabul Tarihi/Accepted: 27 Mayıs 2017

Yazışma Adresi: Nurdoğan Ata

Gaziantep 25 Aralık Devlet Hastanesi KBB

Kliniği, Gaziantep

e-posta: nurdoganata@mynet.com

ORCID

Nurdoğan Ata

https://orcid.org/0000-0002-0763-0852

\begin{abstract}
Öz
Rothia dentocariosa oral kavite ve solunum yolu normal florasında bulunan gram-pozitif, aerobik bir bakteridir. Baş-boyun bölgesinde nadiren enfeksiyona neden olmalarına rağmen immun supresif bireylerde enfeksiyon etkeni olabilir. Bu makalede akut tonsillit sonrası Rothia dentocariosa'nın etken olduğu parafarengeal apse gelişen 33 yaşında erkek hasta sunulmuştur.Bu olgu literatürde R. dentocariosa'nın etken olduğu ilk parafarengeal apse bildirimidir
\end{abstract}

Anahtar Kelimeler: Rothia dentocariosa, parafarengeal, apse

\begin{abstract}
Rothia dentocariosa is a gram-positive, aerobic bacteria that is a part of the normal flora in the oral cavity and respiratory tract. Although it is a rare cause of head and neck region infection, it may be observed in immunosuppressed individuals. Here we report the case of an 33-year old man who developed parapharyngeal abscess that was caused by $R$. dentocariosa after acute tonsillitis. This is the first case
\end{abstract} report of a parapharyngeal abscess caused by R. dentocariosa in the literature.

Keywords: Rothia dentocariosa, parapharyngeal, abscess

\section{GíRiş}

Parafarengeal apseler günümüzde antibiyotiklerin sık kullanılması ile nadir görülmektedirler. Kafa tabanı ile hiyoid arasında uzanan bu bölgenin apseleri hayatı tehdit eden önemli komplikasyonlara neden olabilirler. Derin boyun enfeksiyonları kültürlerinde aeroblardan Streptococcus pyogenes, S. viridans, Klebsiella pneumoniae, Staphylococcus aureus, and Haemophilus İnfluenzae; anaeroblardan ise sıklıkla Prevotella, Porphyromonas, Fusobacterium ve Peptostreptokok türleri tespit edilmektedir (1). Literatürde Rothia dentocariosa' nın etken olduğu derin boyun enfeksiyonu bildirilmemiştir. $\mathrm{Bu}$ makalede immünitesi sağlam, diyabet, travma ve cerrahi öyküsü olmayan genç erkek hastada görülen Rothia dentocariosa'nın etken olduğu literatürdeki ilk parafarengeal apse olgusu sunulmuştur.

\section{OLGU}

Otuz üç yaşında erkek hasta kliniğimize 10 gündür devam eden boğaz ağrısı, yutma güçlüğü ve sağ kulak

Atıf yapmak için: Ata N, Kılıç S, İnan EF. Rothia Dentocariosa'nın Etken Olduğu Parafarengeal Apse. Selcuk Med J 2019;35(2): 123-125 ağrısı şikayetleriyle başvurdu. Öyküsünden başka bir merkezde bir hafta önce akut tonsillit nedeniyle intramuskuler penisilin $G$ tedavisi düzenlendiği ancak şikayetlerinde düzelme olmadığı öğrenildi. Hastanın sistemik hastalık öyküsü, immunsupresif ilaç kullanımı, yabancı cisim ve travma öyküsü yoktu. Hastanın 10 paket/yıl sigara içme öyküsü mevcuttu.

Orofarenks muayenesinde sağ tonsil hizasında tonsilin medial komşuluğunda farinks posterior duvarından retrofaringeal bölgeye doğru uzanım gösteren üzeri düzgün mukaza ile kaplı $3 \times 2 \mathrm{~cm}$ boyutlarında nodüler görünümde lezyon izlendi. Lezyona abeslang ile bastırılınca fluktuasyon hissedildi ayrıca hassasiyet mevcuttu. Tonsillerin görünümü normaldi. Kulak, burun ve endoskopik larinks muayenesinde patolojik görünüm tespit edilmedi. Boyunda palpasyonla ele gelen kitle tespit edilmedi. Parafarengeal bölgede kitle olması nedeniyle Bilgisayarlı tomografi (BT) görüntüleme tetkik edildi. BT görüntüleme kesitlerinde sağ tonsiller bölgeden başlayıp aşağıda retrofarengeal alana

Açıklama: Yazarların hiçbiri, bu makalede bahsedilen herhangi bir ürün, aygut veya ilac ile ilgili maddi sıkar ilişkisine sahip değildir Araştırma, herhangi bir dis organizasyon tarafından desteklenmedi Yazarlar calısmanin birincil verilerine tam erişim izni vermek ve derginin talep ettiği takdirde verileri incelemesine izin vermeyi kabul etmektedirle 


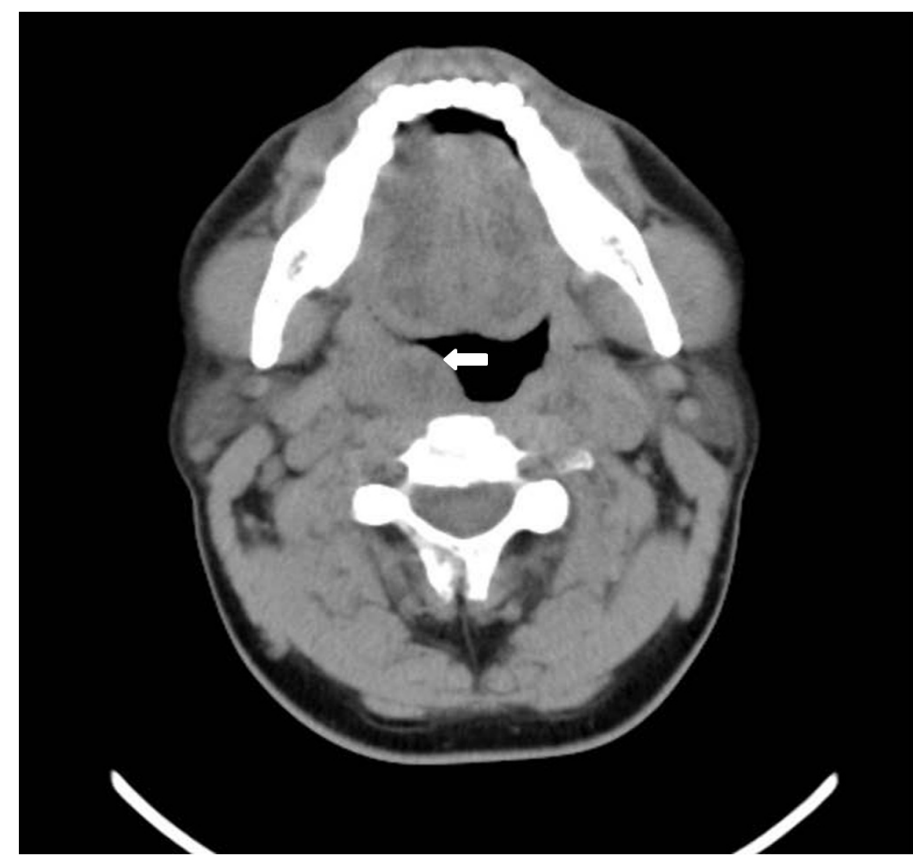

Şekil 1. Aksiyel BT görüntülemede apse (ok).

ilerleyip epiglottik folda ulaşan $27 \times 15 \mathrm{~mm}$ boyutlarında havayolunu kısmi daraltan heterojen apse ile uyumlu lezyon izlendi (Şekil-1,2.)

Hastaya klinik ve radyolojik olarak parafarengeal apse tanısı kondu. Poliklinikte transoral yaklaşımla apsenin iğne ile drenajı yapılarak 4 cc püy

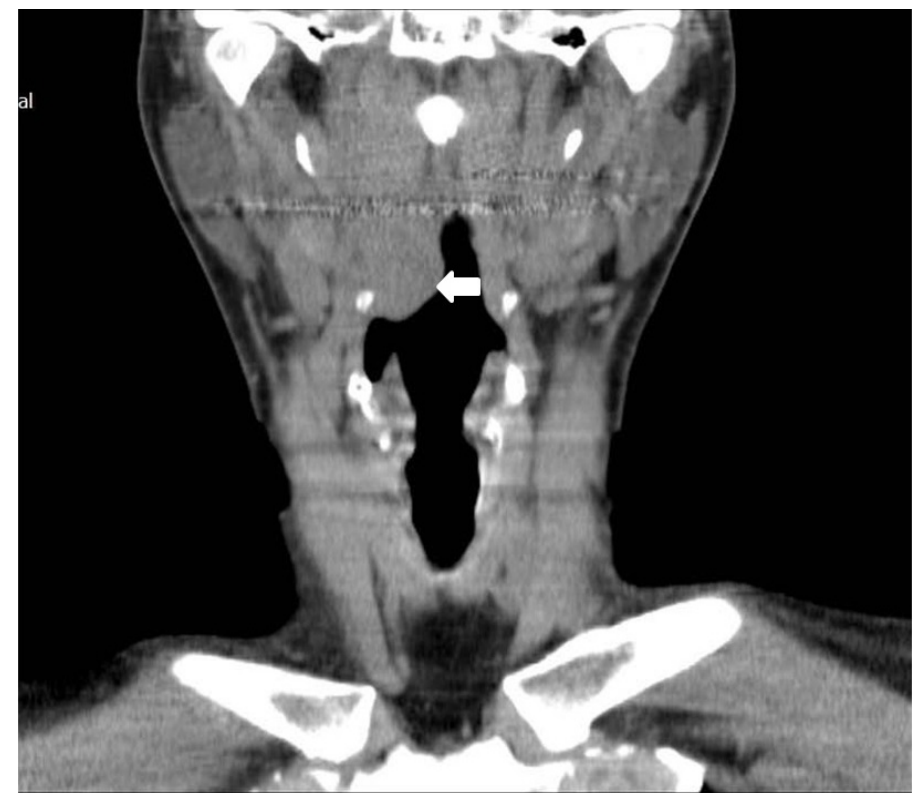

Şekil 2. Koronal BT görüntülemede parafarengeal apse (ok). boşaltılarak kültür için gönderildi. Hastaya ampirik olarak oral amoksisilin/klavunat ve metranidazol başlandı. Hasta bir gün sonra kontrole geldiğinde yeni apse oluşumu izlenmedi ayrıca şikayetlerinde azalma mevcuttu. Aspirasyon materyalinin kültüründe Rothia dentocariosa üredi. Antibiyogramda bakterinin amoksisilin/klavunat, siprofloksasin ve amikasin antibiyotiklerine duyarlı olduğu ancak eritromisin, klindamisin ve trimetoprim/sulfametoksazol direnci olduğu görüldü. Hastaya ampirik olarak başlanan oral amoksisilin/klavunat tedavisine devam edildi. Tedavinin beşinci gününde hastanın semptomu yoktu. Rothia dentocariosa'nın diş çürüğü ve periodontal hastalıklarla ilişkisi olması nedeniyle hastaya diş hijyeni önerildi.

\section{TARTIŞMA}

Antibiyotiklerinkullanımı ilebirlikte insidansıazalmış olmakla birlikte derin servikal faysa yaprakları arasında görülen derin boyun enfeksiyonları halen günümüzde hayatı tehdit eden bir durumdur. Peritonsiller apseler dahil edilmezse en sık submandibular ikinci sıklıkla ise parafarengeal bölge enfeksiyonları görülmektedir $(1,2)$. Parafarengeal bölgenin peritonsiller bölgeden sonra en sık tutulan derin boyun alanı olduğunu bildiren serilerde vardır (3). Parafarengeal boşluk ters koni şeklinde bir alan olup kafa tabanından hyoid kemiğe kadar uzanmaktadır. Prestiloid ve poststiloid olmak üzere iki bölüme ayrılan bu boşluk sıklıkla başka bir bölgenin enfeksiyonu ile etkilenebilir ve enfeksiyonun diğer bir bölgeye geçiş yolunu oluşturabilir (4).

Parafarengeal apseler nadir görülmelerine rağmen hayatı tehdit eden havayolu enfeksiyonu, internal juguler ven trombozu, karotid arter erozyonu, septik şok ve mediastenit gibi ciddi komplikasyonlara neden olabilirler (5). Parafarengeal apseler çocuklarda daha sık görülmektedir. Diyabetik ve immun sistemi zayıf yetişkinlerde de görülme sıklığı fazladır. Bu bölgenin enfeksiyonları genellikle tonsillofarenjit gibi üst solunum yolu enfeksiyonları ve odontolojik enfeksiyonlarasekondergelişirler(4). Sunulanolgunun hikayesinden de tonsillit sonrası parafarengeal apse geliştiği anlaşılmaktadır.

Parafarengeal apselerde ağrı, ateş, disfaji ve odinofaji en sık semptomlardır. Boyunda şişlik, solunum sıkıntısı, trismus ve muayenede palatin tonsilin mediale yer değiştirmesi eşlik edebilir. Ayrıca komplikasyon gelişirse horner sendromu, septik şok, mediastenit, karotis arter kanaması, kavernöz sinüs trombozu ve septik embolizasyona bağlı semptomlar görülebilir (6). Parafarengeal apse tanısı 
genellikle klinik bulguların radyolojik görüntüleme ile desteklenmesiyle konulur. BT ve manyetik rezonans (MR) görüntülemeler ile apsenin vertebra ön duvarı, parafarengeal, retrofarengeal bölgeler ve orofarenks ile ilişkisi değerlendirilebilir. MR görüntülemede apse T1 kesitlerde hipointens, T2 kesitlerde ise hiperintens görünmektedir (7). Ultrason görüntüleme tanıda kullanıldığı gibi görüntüleme eşliğinde apsenin iğne ile drenajınada olanak sağlayabilmektedir (8).

Parafarengeal apseler drenaj ve antibiyoterapi ile tedavi edilirler. Drenaj iğne drenajı yada insizyon drenajı şeklinde yapılabilir. Apse drenajında eksternal yada lateral boyun yaklaşımı ve intraoral yaklaşım olmaküzere iki yöntem vardır. Apsenin lokalizasyonuna ve boyutuna göre yaklaşım değişebilir. Küçük çaplı ve intraoral yoldan kolay ulaşılabilir apselerde intraoral iğne drenajı kolay, komplikasyonu az ve etkili bir yöntemdir. İğne drenajının yetersiz kaldığı durumlarda intraoral yada eksternal insizyon drenajı gerekmektedir. İntraoral yaklaşımın eksternal insizyon ile drenaja göre üstünlükleri hastada skar izi bırakmaması, önemli damarlarda yaralanmaya neden olmaması ve hastanede yatış süresinin daha az olmasıdır $(4,9)$. Sunulan olguda apse intraoral iğne drenajı ile tamamen boşaltılmış ve hospitalizasyon gerektirmemiştir.

Parafarengeal apse drenaj mayi kültüründe genellikle mikst bakteriler üremektedir. Bu nedenle ampirik antibiyotik tedavisi anaerop ve aerop bakterilere etkili olacak şekilde düzenlenmelidir. Sıklıkla etken olan aeroblar alfa ve gama hemolitik streptokoklar, s.aureus, grup A hemolitik streptokoklar ve Neisseria türleridir. Fusobacterium nucleatum, Bacteroid melaninogenicus ve Peptostreptokoklar ise baskın olan anaeroblardır $(1,10)$. Rothia dentocariosa gram-pozitif, aerobik, katalaz-pozitif ve pleomorfik yapıda bir bakteridir. Önceleri bu bakteriler Actinomyces ve Nocardia türlerine dahil edilmiş ancak bakteri duvar yapısını farklı olması nedeniyle ayrı bir grup olduğu bildirilmiştir (11). Rothia dentocariosa genellikle diş çürüğü ve periodontal enfeksiyonlara neden olmaktadır. Bu bakterinin sistemik enfeksiyonu nadir olmakla birlikte literatürde en sık endokardit ikinci sıklıkla ise protez enfeksiyonları yaptığı bildirilmiştir. Ayrıca immunsupresif ve diyabetik hastalarda ciddi enfeksiyonlara neden olabilirler (12).

Pubmed ve Medline veri tabanlarını incelediğimizde Rothia dentocariosa'nın etken olduğu derin boyun enfeksiyonuna ait literatür bilgisi bulunmamaktadır. Bizim olgumuz Rothia dentocariosa'nın etken olduğu literatürdeki ilk parafarengeal apse olgusudur.
Çıkar Çatışması: Çalışmada herhangi bir çıkar çatışması yoktur.

Finansal Çıkar Çatışması: Çalışmada herhangi bir finansal çıkar çatışması yoktur.

Yazışma Adresi: Nurdoğan Ata, Gaziantep 25 Aralık Devlet Hastanesi KBB Kliniği, Gaziantep.

E-posta: nurdoganata@mynet.com

\section{KAYNAKLAR}

1. Huang TT, Liu TC, Chen PR, et al. Deep neck infection: Analysis of 185 cases. Head Neck 2004;26:854-60.

2. Chen MK, Wen YS, Chang CC, et al. Predisposing factors of life-threatening deep neck infection: Logistic regression analysis of 214 cases. J Otolaryngol 1998;27:141-4.

3. Ridder GJ, Technau-Ihling K, Sander A, et al. Spectrum and management of deep neck space infections: An 8-year experience of 234 cases. Otolaryngol Head Neck Surg 2005;133:709-14.

4. Alaani A,Griffiths H,Minhas SS, et-al. Parapharyngeal abscess: Diagnosis, complications and management in adults. Eur Arch Otorhinolaryngol 2005;262:345-50.

5. Oh JH, Kim Y, Kim CH. Parapharyngeal abscess: Comprehensive management protocol. ORL J Otorhinolaryngol Relat Spec 2007;69:37-42.

6. Koivunen $\mathrm{P}$, Lopponen $\mathrm{H}$. Internal carotid artery thrombosis and Horner's syndrome as complications of parapharyngeal abscess. Otolaryngol Head Neck Surg 1999;121:160-2.

7. Diom ES, Ndiaye C, Djafarou $A B$, et al. A case of cervical Pott's disease revealed by parapharyngeal abscess. Eur Ann Otorhinolaryngol Head Neck Dis 2011;128:151-3.

8. Duque CS, Guerra L, Roy S. Use of intraoperative ultrasound for localizing difficult parapharyngeal space abscesses in children. Int J Pediatr Otorhinolaryngol 2007;71:375-8.

9. Amar YG, Manoukian JJ. Intraoral drainage: Recommended as the initial approach for the treatment of parapharyngeal abscesses.Otolaryngol Head Neck Surg 2004;130:676-80.

10. Gidley PW, Ghorayeb BY, Stiernberg CM. Contemporary management of deep neck space infections. Otolaryngol Head Neck Surg 1997;116:16-22.

11. Von Graevenitz A. Rothia dentocariosa: Taxonomy and differential diagnosis. Clin Microbiol Infect 2004;10:399-402.

12. Ozan F, Öncel ES, Duygulu F, et al. Prosthetic hip joint infection caused by Rothia dentocarios. Int J Clin Exp Med 2015;8:11628-31 